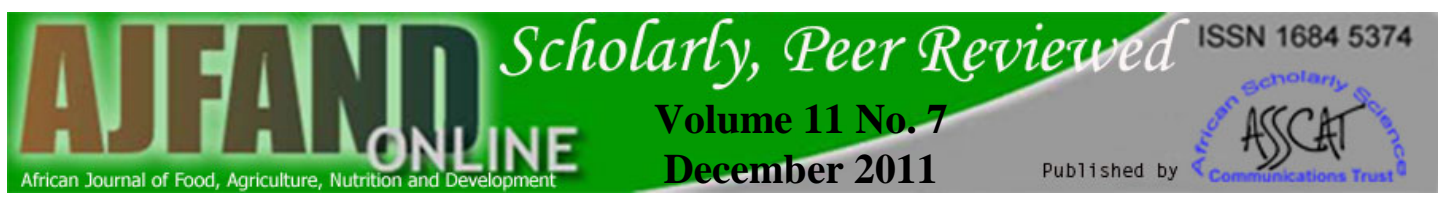

\title{
ROLES AND CAPACITY OF DUTY BEARERS IN THE REALIZATION OF THE HUMAN RIGHT TO ADEQUATE FOOD IN UGANDA
}

\section{Rukundo $\mathrm{PM}^{1^{*}}$ Kikafunda $\mathrm{JK}^{2}$ and A Oshaug ${ }^{3}$}

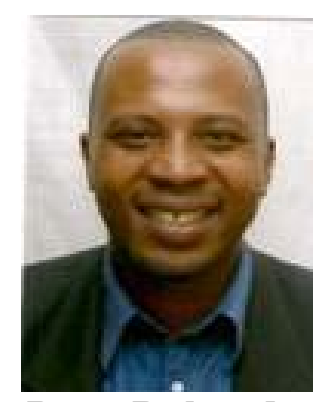

Peter Rukundo

*Corresponding author email: rukpeter@hotmail.com

${ }^{1}$ Department of Human Nutrition and Home Economics, Kyambogo University Faculty of Vocational Studies, P.O.Box 1, Kampala, Uganda.

${ }^{2}$ Department of Food Technology and Nutrition, Makerere University School of Food Technology, Nutrition and Bio-Engineering, P.O.Box 7062, Kampala, Uganda.

${ }^{3}$ Department of Health, Nutrition and Management, Faculty of Health Sciences, Oslo and Akershus University College of Applied Sciences, Postbox 4, St. Olavsplass, 0130 Oslo, Norway. 


\section{ABSTRACT}

The right to adequate food recognised under international law provides a strong foundation for eradicating hunger and malnutrition in all nations. Uganda ratified the International Covenant on Economic, Social, and Cultural Rights (ICESCR) in 1987 and thereby committed itself to ensure the realization of the right to adequate food recognised under Article 11 of the Covenant. This study analysed the roles and capacity of duty bearers in the realization of the right to adequate food in Uganda. Structured interviews were held with purposefully selected duty bearers from 11 districts in the country between February and July 2007. Districts were selected by criterion based sampling. Relevant policies, budgets, and legislation were also reviewed, particularly with state obligations on human rights, and capacity of duty bearers in mind. Although this right is expressly recognised in the Food and Nutrition Policy of 2003 in which a multi-sectoral approach is proposed, sector-specific roles are not explicitly defined in Uganda's institutional and policy framework. Most duty bearer (63\%) considered the Ministry of Agriculture, Animal Industry and Fisheries (MAAIF) as being responsible for the delays in implementing the relevant actions for the right to food. The Uganda Human Rights Commission (UHRC) reported receiving inadequate budget resources to support the right to food. Only $20 \%$ of duty bearers had knowledge of the General Comment 12, which is an important United Nations instrument that defines and elaborates on the human right to adequate food. Duty bearer's knowledge of the right to food in the national Constitution had a significant $\left(\mathrm{X}^{2}=0.003\right.$; $\left.\mathrm{P}<0.05\right)$ positive correlation $(\mathrm{R}=0.283)$ with membership status to an ad hoc Uganda Food and Nutrition Council (UFNC). A proposed Food and Nutrition Bill had taken over 10 years without being presented to the National Parliament for the process of enactment into law. As such, most of the support for this right came from development partners. Whereas the ministry of health and MAAIF are line ministries in the implementation of food and nutrition policy, the right to food roles of the various duty bearers in Uganda need to be well defined. Capacity development is also needed, particularly related to integrating right to food sector-specific roles into the theoretical development and practical implementation of food and nutrition security programmes at all levels in the country.

Key words: Right to adequate food capacity 


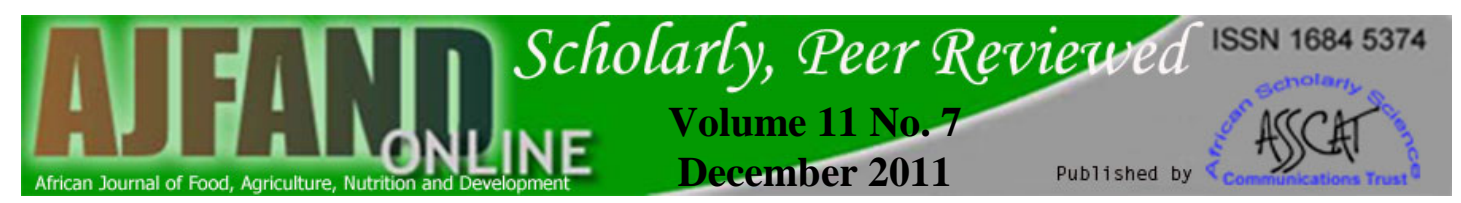

\section{INTRODUCTION}

\section{Background}

The human right to adequate food is realized when every man, woman and child, alone or in the community with others, have physical and economic access at all times to safe, sufficient and nutritious food or means for its procurement [1]. Uganda is a party to various international commitments to food and nutrition including the Millennium Declaration whose $1^{\text {st }}$ Millennium Development Goal (MDG 1) aims to eradicate poverty and hunger. It ratified the International Covenant on Economic, Social, and Cultural Rights (ICESCR) in 1987 and recognized the right to adequate food in Objectives XIV and XXII of the 1995 Constitution of the Republic of Uganda (CRU) [2].

In 1997, Uganda like other Highly Indebted Poor Countries (HIPC) adopted a Poverty Reduction Strategic Paper (PRSP) as a basis for debt relief and Poverty Reduction Support Credit (PRSC) from the World Bank and the International Monetary Fund (IMF). The PRSP was adopted as the "Poverty Eradication Action Plan (PEAP)", an overall policy framework that was reviewed every five years [3]. In effect, the Government of Uganda instituted the Plan for Modernisation of Agriculture (PMA) Secretariat in the year 2000 to fast-track agricultural transformation and food security through commercialised agriculture $[4,5,6]$.

Within the context of the PEAP and the PMA, the Uganda Food and Nutrition Policy (UFNP) was adopted in 2003 with the right to adequate food as its guiding principle [7]. Based on this Policy, a multisectoral Uganda Food and Nutrition Council (UFNC) was proposed to guide the implementation and monitoring of food and nutrition programmes. The Ministry of Agricultural, Animal Industry, and Fisheries (MAAIF) and the Ministry of Health (MOH) are the line ministries in the implementation of the UFNP. Subsequently, a National Food and Nutrition Strategy (NFNS) to guide the implementation of the Policy was drafted in 2005 with emphasis to shift from a 'basic needs approach' to a 'human rights based approach' to food and nutrition security [8].

In spite of the aforementioned commitments to provide food security, the country suffers a high malnutrition burden in children aged 6-59 months: mortality associated with malnutrition was estimated at over $40 \%$; chronic malnutrition indicated by stunting was at 38\%; acute malnutrition indicated by wasting was $6 \%$; while underweight was $16 \%$ [9]. The consequence of childhood malnutrition and related mortality in Uganda is not limited to infections, but also poor immune function due to inadequate dietary intake and care in infancy and childhood [10].

By 2006, more than one third of the estimated 30 million Ugandans were living under conditions of income poverty - with less than one United States dollars per day [11], while an estimated $19 \%$ of the population were reported to be undernourished [12]. The Food and Agriculture Organization of the United Nations (FAO) subsequently indicated in 2008 that the situation had not improved due to a global financial crisis that resulted into increased food and fuel prices [13].

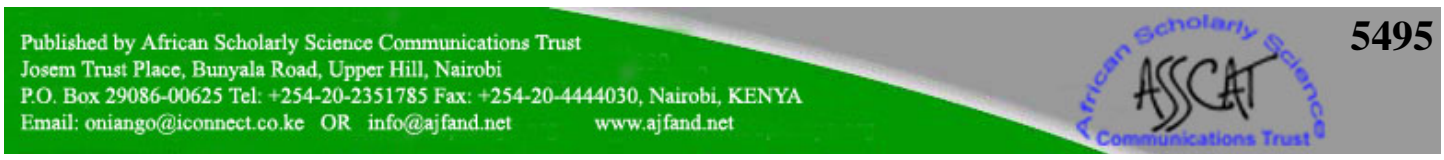




\section{Objectives of the study}

Based on existing institutional and legislative frameworks in Uganda, and its State Party obligations and commitments to the ICESCR and other relevant human rights instruments, the objective of this study was to analyse the roles and capacity of duty bearers to develop and implement policies and legislation to ensure availability and access to adequate food by citizens of Uganda.

\section{MATERIALS AND METHODS}

\section{Study design and respondents}

This study was a non-experimental design that involved a cross-sectional role and capacity analysis of relevant duty bearers considered as elected, appointed, or delegated authorities relevant to the implementation of food and nutrition policy, and the realization of the human right to adequate food in Uganda. Role analysis involved assessing performance of duty bearers in meeting their obligations and responsibilities, taking into account their efforts and achieved results [14, 15]. Capacity analysis involved assessing the ability of actors to meet the obligations required of them using available resources [16, 17].

A total of 109 duty bearers were selected by purposive sampling from 11 districts of Uganda - Kampala, Gulu, Katakwi, Soroti, Kayunga, Jinja, Rakai, Kasese, Bushenyi, Mbarara, and Kisoro. The districts were selected by criterion-based sampling, such as events, settings, and activities impacting the right to adequate food. Conflict related internally displaced persons (IDPs) were a basis for selecting Gulu district from the north, and Katakwi and Soroti districts in the north east. Rakai district in the south was selected on the basis of the effect of HIV/AIDS. The other districts from the south west were selected on the basis of high reported levels of undernutrition despite being among the largest food producing districts in the country. The capital city of Kampala was a core site of the study given that it is where the headquarters of most of the relevant institutions are situated.

Out of the 109 respondents, $48 \%$ (52) were district and village council leaders, 11\% (12) were from the food and nutrition line ministries of MAAIF and $\mathrm{MOH}, 23 \%$ (25) were from other ministries and institutions represented on the ad hoc Uganda Food and Nutrition Council (UFNC), 12\% (13) were Members of Parliament, and 6 \% (7) were from the Judiciary.

\section{Data collection and analysis}

The study employed both qualitative and quantitative methods of data collection. Face-to-face interviews guided by an objectives-based semi-structured questionnaire were used on duty bearers from institutions at the national and district level, while a checklist of open-ended questions was used with local council authorities in the districts. 
Qualitatively, content analysis of relevant policies, strategies, legislation, and budgets frameworks was a continuous process before, during, and after data collection. Phenomenology techniques including real time analysis were employed as an ongoing analysis process during the interviews [18]. It included qualitative evaluation of attitudes, intentions and perceptions to the right to adequate food. Quantitatively, statistical analysis using the Statistical Package for Social Scientists (SPSS) version 12, involved the use of Pearson Chi-Square to test, at significant level $\mathrm{P}<0.05$, whether institutional membership to the UFNC was related to knowledge of provisions on the right to food in Uganda's Constitution [2], and in General Comment 12 [1]. The Spearman Correlation and the Fishers Exact test were used to validate Chi-Square results given the relatively small sample size.

A right to adequate food obligation matrix, which illustrates a cross linkage of the State's obligations to respect, protect, and fulfil human rights, against the component of nutrition security (food security, care, and health), was adapted as an interdisciplinary and intersectoral tool for analysing roles and capacity to realise the right to adequate food within the context of food and nutrition security [19].

\section{RESULTS}

\section{Institutional roles, policy and legal framework for right to food in Uganda}

In 1987, Uganda ratified the International Covenant on Economic, Social, and Cultural Rights (ICESCR) and pledged to ensure the right to food in the context of food security and nutrition in Objectives XIV and XXII of the 1995 Constitution of the Republic of Uganda. Objective XXII specifically provides that, "The State shall: a) take appropriate steps to encourage people to grow and store adequate food; b) establish national food reserves; and, c) promote proper nutrition through mass education and other appropriate means required to build a healthy State.”

As illustrated in the Figure 1, an important but ad hoc (non-legally institutionalised) Uganda Food and Nutrition Council (UFNC) has been influencing policy and legislation affecting the right to food in the context of food and nutrition security. Despite absence of a legal mandate, the UFNC has since 1987 been considered as a multisectoral forum of technical persons from stakeholder institutions relevant to the improvement of food and nutrition. In addition to the Ministry of Agriculture, Animal Industry and Fisheries (MAAIF) and the Ministry of Health (MOH) which are the food and nutrition line ministries, other institutions represented on the UFNC include the: Ministry of Gender, Labour, and Social Development (MGLSD); Ministry of Finance, Planning, and Economic Development (MFPED); Ministry of Education and Sports (MOES); Ministry of Local Government (MLG); Uganda National Bureau of Standards (UNBS); Ministry of Trade, Tourism and Industry (MTTI); the Plan for Modernization of Agriculture (PMA); Institutions of Higher Leaning; Civil Society Organisations (CSO); Farmers groups; and the Private Sector. 

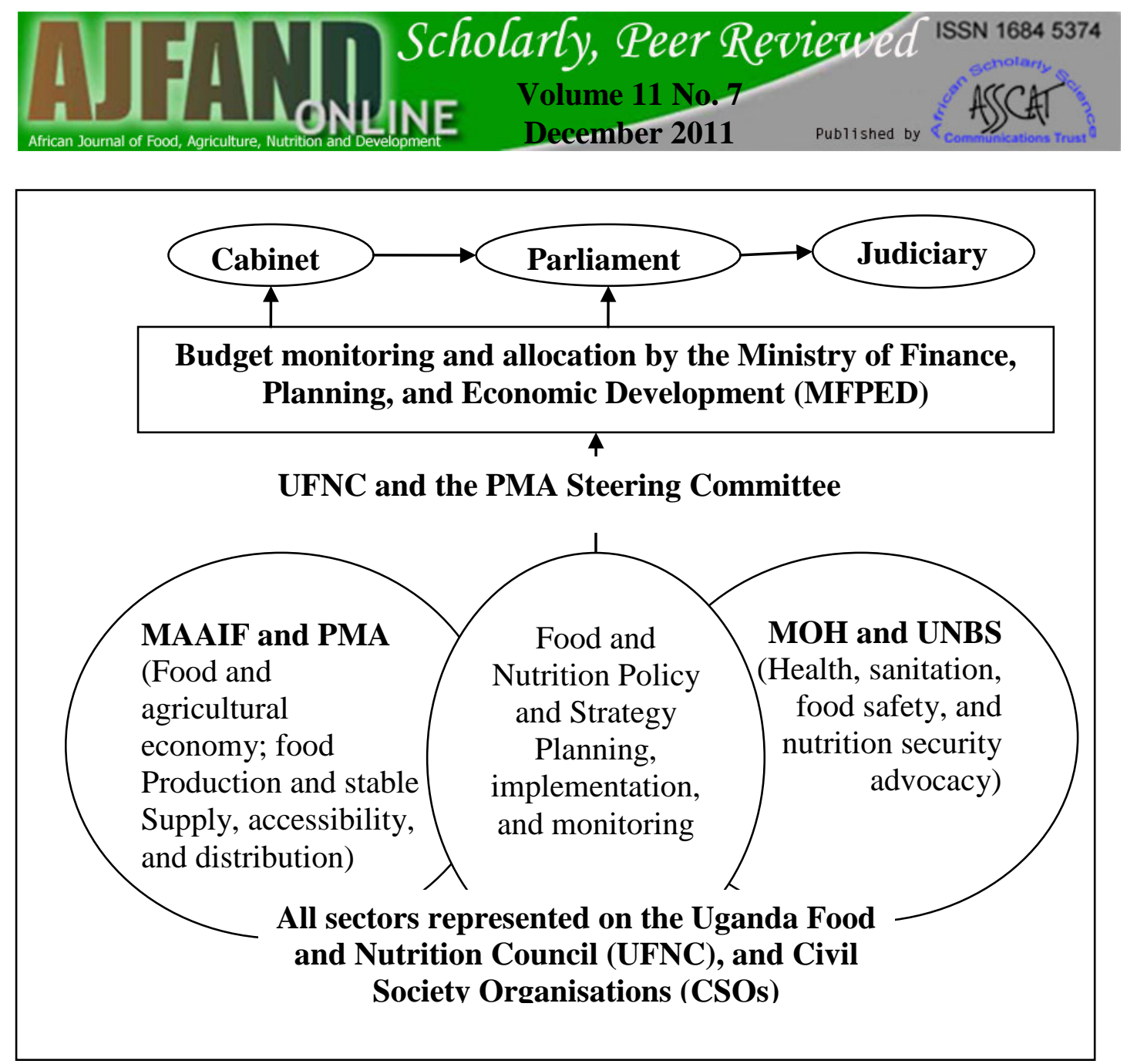

Figure 1: Institutional framework supporting the right to food in the context of food and nutrition security in Uganda

In addition to the majority representation of government ministries (69\%), a policy gap identified by this study is the omission of the Office of the Prime Minister (OPM) in the structural framework of UFNC as proposed in the UFNP of 2003. Apparently, the Ministry of Disaster Preparedness and Relief (DPR) under the Office of the Prime Minister (OPM) is obliged to provide and coordinate humanitarian disaster response and food relief to the most vulnerable in time of disasters and emergencies. However, the role and obligations of the DPR and OPM generally, have not been included in the food and nutrition policy framework [7]. In addition, the Uganda Human Rights Commission (UHRC), an institution mandated by Article 52 of the 1995 Constitution of the Republic of Uganda (CRU) to monitor all human rights including the right to adequate food [2], is also omitted from the food and nutrition policy framework.

As seen in Table 1, this study established that there was limited knowledge of the constitutional provisions in objectives XXII; only 39\% (42) were aware of States commitment to Food Security and Nutrition in the 1995 CRU. This implied a challenge for some duty bearers to appreciate and promote a constitutionally mandated obligation on food and nutrition. In addition, only $22 \%$ of duty bearers were aware about the United Nations General Comment 12 (GC 12) on the human right to adequate food. This also showed low levels of duty bearer's civic awareness on the 


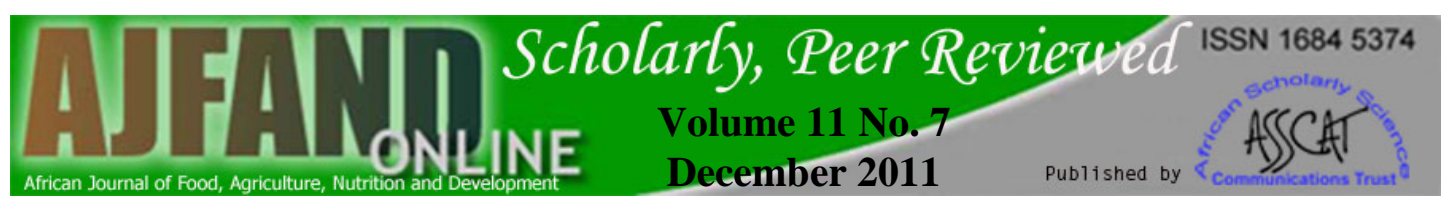

State obligations and commitments on the right to food in accordance to international law.

In the absence of a national right to food strategy, this study did not establish specific institutional roles on the right to adequate food in Uganda. Whereas international law describes the State as having the primary obligation to ensure the right to adequate food of its people, $56 \%$ (61) perceived this right as an obligation of United Nations (UN) agencies such as the World Food Programme (WFP).

Pearson Chi-Square test at significant level of $\mathrm{p}<0.05$, on the relationship between membership status to the UFNC and knowledge of obligations stipulated in national and international human rights instruments (Objective XXII, and GC 12) yielded a positive relationship $\left(X^{2}=8.739, P=0.003\right.$ and $X^{2}=6.021, P=0.009$ respectively). Correlation coefficient were also positive ( $r=0.283$ and $r=0.351$, respectively). This implied that more members from UFNC represented institutions were aware of relevant instruments and legal provisions on the right to adequate food at national and internal level as compared to those from institutions not represented on the UFNC. In essence, this would justify the need for further civic awareness of this right, especially among other relevant institutions not represented on the UFNC.

Despite the multi-sectoral approach recommended in the Uganda Food and Nutrition Policy of 2003, most duty bearers (63\%) considered the Ministry of Agriculture, Animal Industry and Fisheries (MAAIF) as being responsible for the delays in adopting and implementing the relevant actions to ensure the right to adequate food in country. In addition 5 of the interviewed 6 duty bearers from the Ministry of Health $(\mathrm{MOH})$ reported that the right to adequate food was not their mandate in spite of this institution being a food and nutrition line ministry. This implied a gap in the interpretation of a multi-sectoral approach emphasised in the realization of the right to food in the context of the UFNP.

The study did not establish any specific legislation that explicitly defined the right to food roles of relevant institutions of the State. The Food and Drug Act (FDA) adopted in 1959 when Uganda was still a British Protectorate is out of date and essentially regulated food quality and safety [20]. In 1993, the FDA was revised to provide for the institutionalisation of the National Drugs Authority (NDA) and the Uganda National Bureau of Standards (UNBS). Consequently, a Food and Nutrition Bill and a Food Safety Bill were also proposed. However, despite 15 years of negotiations and waiting, the two draft legislations had not been enacted into Law at the time of the study.

In collaboration with the Ministry of Trade, Tourism, and Industry (MTTI) and other stakeholders, the $\mathrm{MOH}$ is also the lead institution enforcing Statutory Instrument 2781 that regulates the Marketing of Infant and Young Child Foods in Uganda [21]. This legal instrument is central in protecting the right of infants and children to breast milk, in accordance to the Innocenti Declaration on the Protection, Promotion, and Support of Breastfeeding, and the Code of Marketing and Promotion of Breast Milk Substitutes, adopted by the World Health Assembly in 1981. 
In addition, "The Children's Statute” of 1996 provided for the establishment of the National Council of Children (NCC). It places obligations on the State and responsibility on parents to ensure adequate care of children in Uganda. In effect, Sections 157 of the "Penal Code Act" (PCA) makes it legally possible to accuse and charge parents in court of law, for neglecting to provide food to children under their care by stating that:

"Anyone with authority to care for any child who refuses or neglects to provide sufficient food, clothing, bedding, and other necessaries for the child, so as thereby to injure the child, commits a misdemeanour".

This would be interpreted as an offence punishable by a jail sentence of up to one year and or a fine.

Other legislation that may support the progressive realization of the right to adequate food in Uganda include among others: "The Water Statute" of 1995; "The Adulteration of Produce Act" of 2000; “The Plant Protection Act” of 2000; "The National Agricultural Advisory Services Act" of 2001; "The Agriculture Chemicals Act" of 2007; and the amended "Land Act" of 1998, which was also being amended at the time when consultations of this study were being undertaken.

Given that legislation is a continuous process, there could be other right to food relevant legal instruments in Uganda. However, most of the identified instruments are neither explicit on the right to food nor specific on duty bearers and institutional roles. Only the "Food and Nutrition Bill", which had been in draft form for over 15 years, had clearly outlined the right to food roles of specific sectors under the stewardship of a proposed multi-sectoral Food and Nutrition Council (UFNC) and Secretariat.

\section{Capacity to implement and monitor the right to adequate food in Uganda}

Most duty bearers (72\%) reported that the State of Uganda lacked the capacity to realise the right to adequate food for all its citizens. Figure 2 illustrates that most duty bearers identified lack of political will (45\%), followed by budget constraints (34\%) and inadequate human resources (14\%) as the main capacity constraints affecting the realization of this right. 

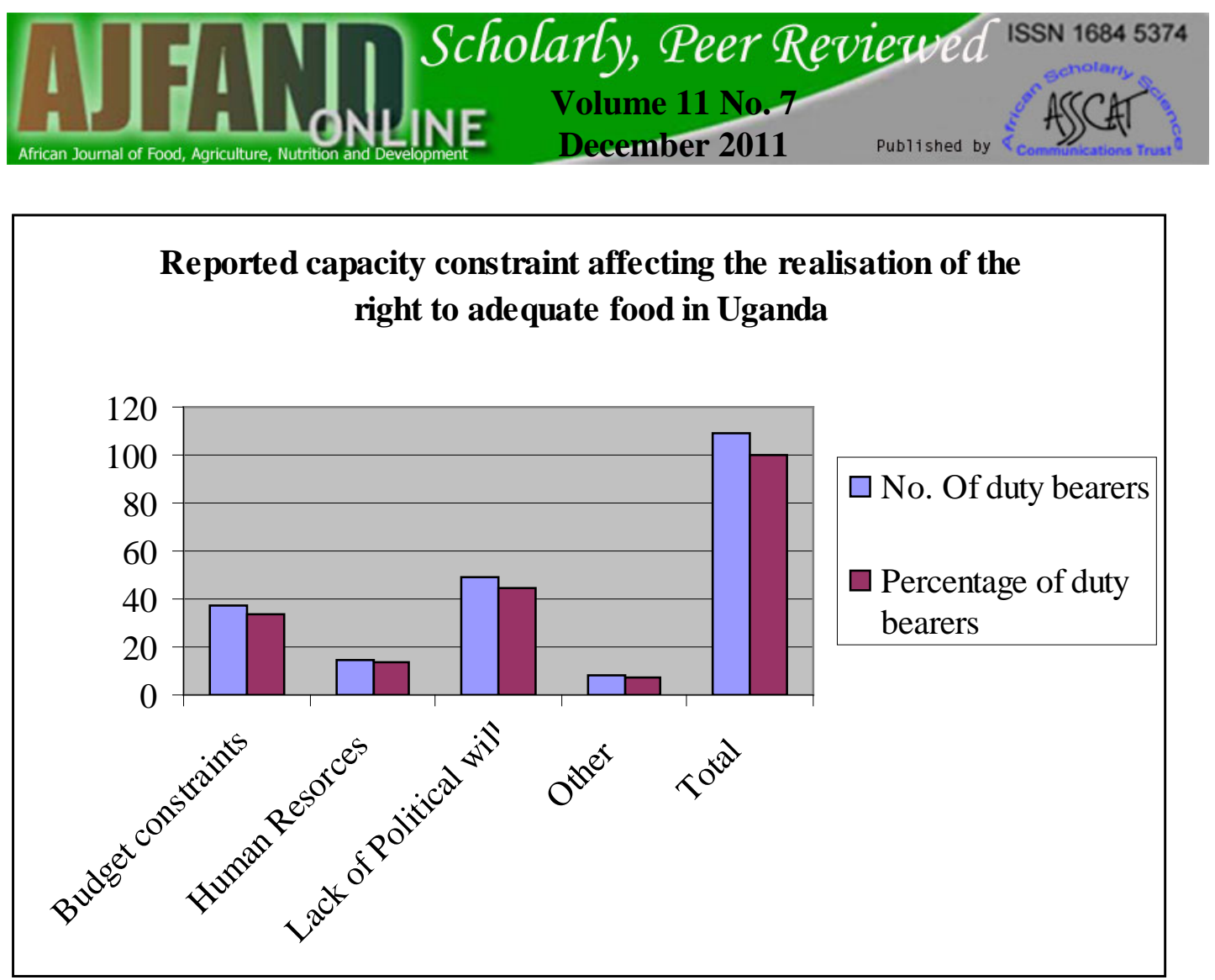

Figure 2: Right to food capacity constraints identified by Uganda's duty bearers

The study further established that administrative recourse mechanisms for extremely vulnerable groups are not clearly instituted into existing implementation frameworks, and there was no clear monitoring framework for the right to adequate food.

Even though Uganda's ratification of the International Covenant on Economic, Social, and Cultural Rights (ICESCR) in 1987 was a commitment to uphold all the provisions therein, it had not submitted periodic State Party reports to the Committee on Economic, Social, and Cultural Rights (CESCR) as obliged by Article 16 and 17 of the ICESCR. In effect, four periodic reports by Uganda were due by 2007. This breach of obligations constitutes a violation by omission of all Economic, Social, and Cultural Rights (ESCR) including the right to adequate food recognised under Article 11 .

The Uganda Human Rights Commission (UHRC) is an independent institution established by Article 51 and mandated by Article 52of the 1995 Constitution of the Republic of Uganda, to monitor, report, and investigate compliance of the State to international treaty and convention obligations on human rights. However, this institution had not prioritised and instituted right to food monitoring and reporting mechanisms. As seen in Figure 3, the UHRC has continuously expressed limited budgetary allocations by the State, including shortfalls of over $50 \%$ since it was established in 1997 [22, 23]. 

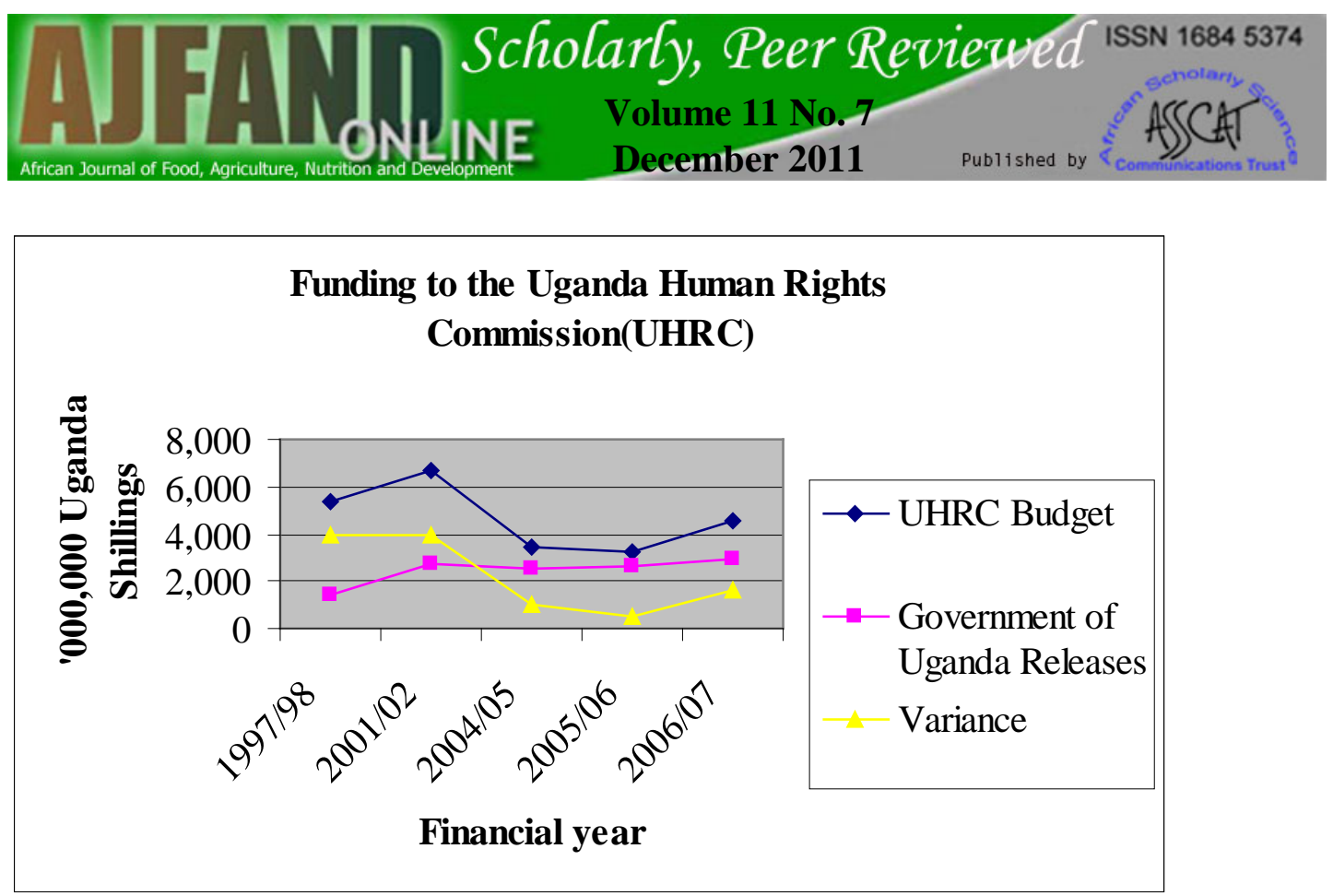

\section{Figure 3: Trends in budget allocation to the Uganda Human Rights Commission from 1997 to 2007}

Food and nutrition security data is a component of the Uganda Demographic and Health Survey (UDHS) performed by the Uganda Bureau of Statistics (UBOS), a semi-autonomous institution under the Ministry of Finance, Planning, and Economic Development (MFPED). The UDHS has been conducted every five years since 1989. However, even the most recent UDHS of 2006 was undertaken using external financing and technical support from the United States Agency for International Development (USAID), the United Nations Population Fund (UNFPA), and ORC Macro from the United States of America among many others [9]. This demonstrated that the UBOS lacks adequate capacity to independently assess food and nutrition security and the right to adequate food in Uganda.

Other information systems relevant for assessing the human right to adequate food in Uganda include the "Household Budget Survey" (HBS) conducted by the MFPED, "Early Warning and Food Information Systems" (EWFIS) conducted by the Gender and Early Warning Unit in the MAAIF, in coordination with the Meteorology Department and the Office of the Prime Minister (OPM). The "National Food Balance Sheets" (FBS) are also developed by the MFPED and MAAIF with support of the Food and Agricultural Organization of the United Nations (FAO). Additionally, "Nutrition Status Assessment Surveys" are being undertaken in various regions of the country by the Ministry of Health, and Development partners. However, a national right to food situation assessment had not been undertaken, and therefore a right to food approach had not been integrated into food and nutrition security assessment and programming. 


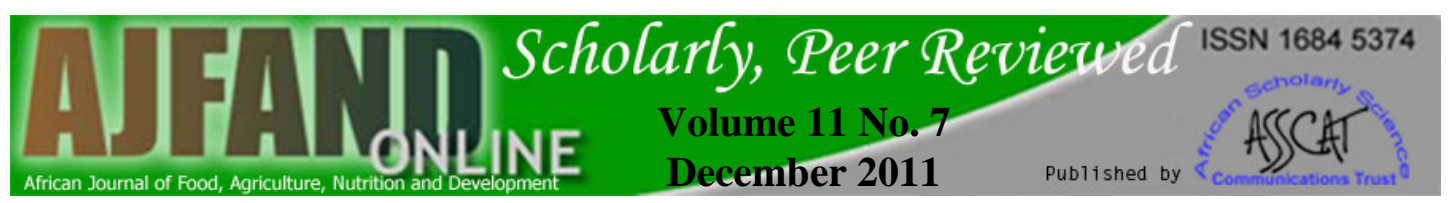

\section{DISCUSSION}

Taking into context the specific roles played by the various ministries and institutions that are represented on the ad hoc Uganda Food and Nutrition Council (UFNC), the Ministry of Agriculture, Animal Industry, and Fisheries (MAAIF) and the Ministry of Health (MOH) are the lead institutions in the implementation of policies relevant to food and nutrition security in Uganda.

Uganda was represented on the Intergovernmental Working Group (IGWG) which developed 19 Guidelines to support United Nations member States in the progressive realisation of the human right to adequate food in the context of national food security [24]. It is also a Party to the 2003 African Union Summit Maputo Declaration on Agriculture and Food, where Africa's Heads of States and Governments pledged to allocate not less than $10 \%$ of their annual budgets to agriculture and food security [25]. However, in this country whose economy is predominately agriculture-based with over $75 \%$ of workforce depending on small scale food production [9, 26], the MAAIF has continuously received less than $5 \%$ of the national budget allocations between the financial years 2000 and 2007 [26, 27, 28].

In view of the commitment to food and nutrition security and the right to food at international [24], regional [25], and national [2, 7] levels, the limited resource allocation to MAAIF demonstrates a lack of political will to prioritise the enhancement of effective food production and distribution systems as one among other means of ensuring stability in supply and access to adequate food as a human right in Uganda. Although a higher share of the budget may not guarantee the effective realization of the right to adequate food, increase in budget allocation to the MAAIF has to be balanced with the adoption of a right to food approach that emphasizes the central positioning of human rights principles and obligations in food and nutrition planning, implementation and monitoring.

In exercise of the obligation of providing food to the most vulnerable Ugandans, the Ministry of Disaster Preparedness and Relief (DPR) under the Office of the Prime Minister (OPM) has been responsive in coordinating humanitarian disaster response and food relief. Whereas this may demonstrate a positive step in the fulfilment of the right to food State obligation [1], the omission of the DPR in UFNC and in Food and Nutrition Policy (UFNP) framework is a technical implementation gap that needs to be addressed.

The relevant duty bearers have not demonstrated the desire for concrete investments to realise the right to adequate food due to a number of challenges that range from delays in implementation due to limited civic awareness and capacity [29], to negative perceptions and inadequate recourse mechanisms to empower vulnerable rights holders who cannot fend for themselves [30]. In addition, the policy by the "National Agricultural Advisory Services" (NAADS) and the "Plan for Modernisation of Agriculture" (PMA) that targets "to achieve food security through the market by empowering the economically active poor" [17, 18, 19], is discriminatory against vulnerable Ugandans who are incapacitated and lack the means to produce or access

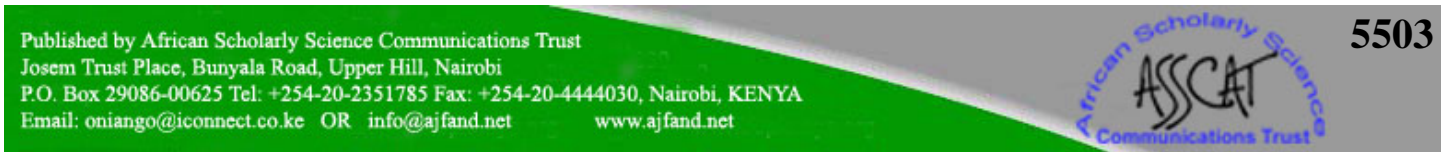




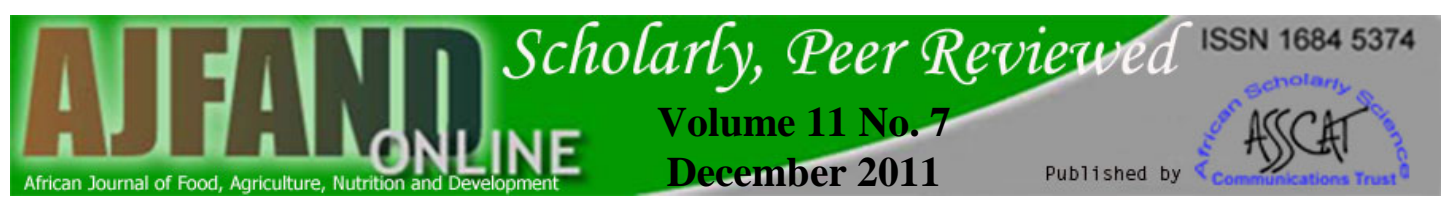

adequate food. In addition, the delayed process of enacting the Food and Nutrition Bill (FNB) into Law is a political challenge affecting capacity to progressively institutionalise duty bearers' roles in realizing the right to adequate food.

In view of the urgency to build capacity to assess underlying and basic causes of malnutrition, other than the routine immediate causes of diet inadequacy and disease $[10,29]$, a systematic national data base system to inform policy decisions on how to intervene in favour of vulnerable groups is a critical requirement for right to adequate food-relevant interventions. In effect, a right to adequate food approach may need to integrate assessment of dietary adequacy and care practices, as a complementary means for identifying nutritionally vulnerable rights holders in need of adequate food.

In the circumstances of inadequate institutional and budget capacity, the opportunity exists in the constitutional mandates and powers of the UHRC as articulated in Article 52 and 53 [2]. Using the available limited resources, the UHRC can involve institutions represented on the UFNC to promote civil awareness, as a means of generating public actions needed to ensure a right to adequate food approach, responsive accountability, and remedial actions in case of violations of the right to adequate food.

Conceptual and ideological challenges in interpreting General Comment 12 [1] and the Voluntary Guidelines on the right to adequate food [24], is a barrier to domestication of relevant provisions and tools for realising the human right to adequate food in Uganda. Efforts to advance State obligations recognised under International Law have often been met with resistance from politicians and development partners who promote private sector and market led economic growth and development at the expense of human rights [30]. Indeed the impression is that the State's Party obligations of respecting, protecting, and fulfilling (facilitate and provide) the right to adequate food are not well understood and appreciated by most duty bearers in Uganda. There is a strong need for a clear elaboration of intersectoral roles in the progressive realisation of this right, within the context of existing policies and legislation. Institutionalised and community focused capacity building and advocacy measures may also empower rights holders to demand accountability from the duty bearers through public actions and other means.

\section{CONCLUSION}

Ensuring an environment where adequate food can be enjoyed as a human right requires capacity and clear roles for continuous preparedness to deal with political and societal threats to humanity. In Uganda, the right to adequate food is recognised in the 1995 Constitution, and in the Food and Nutrition Policy of 2003. However the institutional and legal framework for implementing the policy is not yet in place due to the delayed enactment of the Food and Nutrition Bill into an Act of Parliament. This has led to a policy without a clear direction and focus on the roles and capacity of the relevant institutions and duty bearers. This is an indication of uncertainty on where Uganda is heading when it comes to the human right issue of access to adequate food. 
Given the overriding national development policy objective of poverty eradication, responsible actors in Uganda will need to promote civic education on the human right issue of access to adequate food. Furthermore, it will need to consider developing institutional capacity and mechanisms to address the issues pointed out in the General Comment 12 adopted by the United Nations in 1999, and the framework provided in the Voluntary Guidelines on the right to adequate food (VG), developed by the UN member countries and adopted by the FAO council in 2004. All these efforts would need to have tools, capacity, and clear roles in order to set a process in motion to progressively realise the right to adequate food of Ugandans.

Essentially, right to food capacity building platforms need to be strengthened and streamlined into the education curriculum, using a collaborative approach involving the Uganda Human Rights Commission (UHRC), Parliament, the Ministry of Finance, Planning, and Economic Development (MFPED), Civil Society and other ministries represented on the ad hoc UFNC. This process can provide the means for promoting necessary public policy actions that support the realization of the right to adequate food. Capacity development is thus needed to integrate human rights into the theoretical development and practical implementation of food and nutrition programmes in Uganda. 


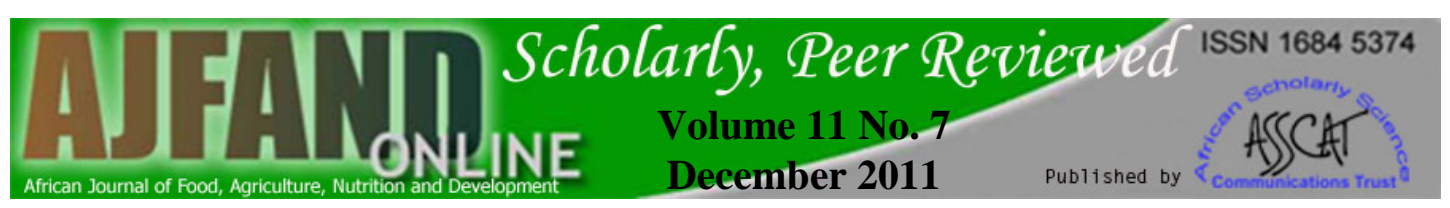

Table 1: Uganda's duty bearer's knowledge on the right to food provisions in national and international law instruments $(n=109)$

\begin{tabular}{|c|c|c|c|c|c|c|}
\hline \multirow[t]{2}{*}{$\begin{array}{l}\text { Membership } \\
\text { status to the } \\
\text { Uganda Food and } \\
\text { Nutrition Council } \\
\text { (UFNC) }\end{array}$} & \multicolumn{3}{|c|}{$\begin{array}{c}\text { Knowledge of Objective } \\
\text { XXII in the } 1995 \\
\text { Constitution of the Republic } \\
\text { of Uganda (\%) }\end{array}$} & \multicolumn{3}{|c|}{$\begin{array}{c}\text { Knowledge of United } \\
\text { Nations General Comment } \\
12 \text { on the right to adequate } \\
\text { food (\%) }\end{array}$} \\
\hline & Yes & $\mathrm{No}$ & Statistical & Yes & No & Statistical \\
\hline UFNC members & 71 & 29 & \multirow{2}{*}{$\begin{array}{l}\text { significance } \\
\text { (P value)* }^{*}\end{array}$} & 53 & 47 & \multirow{2}{*}{$\begin{array}{l}\text { significance } \\
\text { (P value)* }^{*}\end{array}$} \\
\hline Others who are not & 33 & 67 & & 14 & 86 & \\
\hline All respondents & 39 & 61 & 0.003 & 22 & 78 & 0.009 \\
\hline
\end{tabular}

$\mathrm{P}<0.05$ implies that there exists a statistical relationship. *Pearson Chi-square 


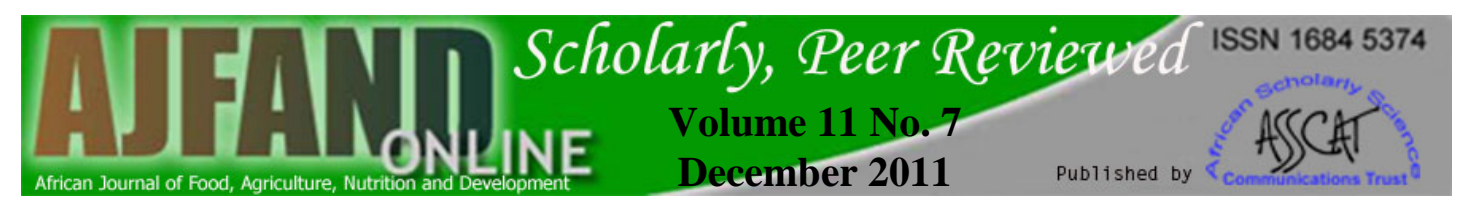

\section{REFERENCES}

1. CESCR (Committee on Economic Social and Cultural Rights of the United Nations) General Comment No. 12: The right to adequate Food. UN document E/C.12/1999/5. Geneva, United Nations, 1999.

2. ROU (Republic Of Uganda) Constitution of the Republic of Uganda, Kampala, 1995.

3. ROU. Poverty Eradication Action Plan 2004/05-2007/08. Kampala, Ministry of Finance, Planning, and Economic Development (MFPED), 2004.

4. Mpeirwe A and D Damulira Rethinking the National Food and Nutrition Policy in Uganda. Kampala, ACODE and VEDCO, 2003.

5. PMA (Plan for Modernisation of Agriculture) Steering Committee Annual Report, Kampala, PMA Secretariat, 2004.

6. PMA Poverty and Gender Sub-Committee PMA Poverty (Gender and Equity Perspectives); Proposed Undertakings for the FY 2007/08, Kampala, PMA Secretariat, 2006.

7. ROU. Uganda Food and Nutrition Policy (UFNP). Kampala, Ministry of Agriculture, Animal Industry, and Fisheries (MAAIF), and Ministry of Health (MOH), 2003.

8. ROU. National Food and Nutrition Strategy (NFNS) - Draft. Kampala, MAAIF and $\mathrm{MOH}, 2005$. http://www.pma.go.ug/nutrition.php [ Accessed 05/06/2007].

9. Uganda Bureau of Statistics (UBOS). Uganda Demographic and Health Survey (UDHS). Kampala and Maryland, UBOS and Macro International Inc. 2007, pp 153-173.

http://www.ubos.org/publications/dhs/Uganda\%20DHS\%202006\%20Final\%2 0\%20Report.pdf [Accessed 14/10/2007].

10. Kikafunda JK, Walker FA, Collett D and JK Tumwine Risk Factors for Early Childhood Malnutrition in Uganda. American J. of Pediatrics. 1998; 102(4): e45. http://pediatrics.aappublications.org/cgi/content/full/102/4/e45 [Accessed 7/05/2007].

11. UNDP (United Nations Development Programme) Uganda Human Development Report (UHDR). Kampala, UNDP, 2006.

http://www.ullndp.or.ug/ [Accessed 22/08/2007].

12. FAO (Food and Agriculture Organization of the United Nations) State of Food Insecurity in the World. Ending World Hunger - taking stock ten years after the World Food Summit, Rome, FAO, 2006. 


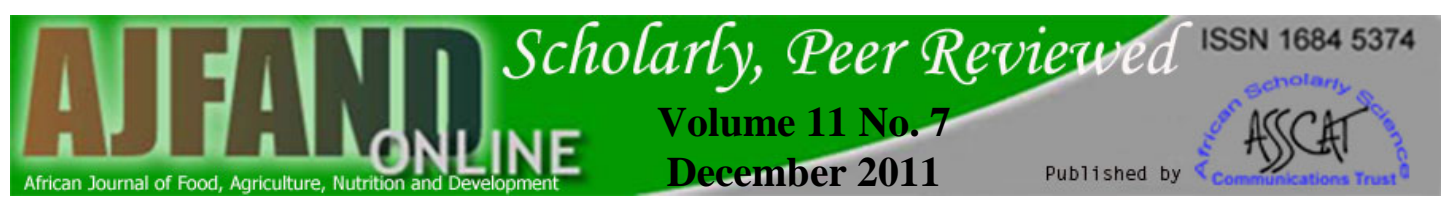

13. FAO. State of Food Insecurity in the World. High food prices and food security - threats and opportunities, Rome, FAO, 2008.

14. Jonsson U Human Rights Approach to Development Planning. Nairobi, UNICEF, 2003.

15. Engesveen $\mathbf{K}$ Monitoring the realisation of the human right to adequate food; Role and capacity analysis in breastfeeding policy and practice. A Case study of the Maldives. Oslo, University of Oslo, 2005.

16. UNICEF (United Nations Children's Fund) Strategy for improved nutrition for children and women in developing countries. United Nations Children's Fund Policy Review, UN doc.E/ICEFF/1993/L.6, 1990.

17. Sabatini F Programming with a Human Rights Approach: A UNICEF experience in operational practice. In: Eide WB and U Kracht (Eds). Food and Human Rights in Development. Volume I. Antwerpen, Intersentia, 2005; 10: 229-258.

18. Robson C Real World Research: A Resource for Social Scientists and Practitioner - Researchers. $2^{\text {nd }}$ Edition: Oxford and Cambridge, Blackwell Publishers, 2002.

19. Oshaug A, Eide WB and A Eide Human Rights: A normative basis for food and nutrition-relevant policies. Food policy 1994; 19(6):491-516.

20. ROU. The Laws of the Republic of Uganda, Chapter 278 - the Food and Drugs Act, Kampala, 2000. ftp://ftp.fao.org/codex/ccafrica16/ca1606ae.pdf [Accessed 28/09/2007].

21. ROU. The Laws of the Republic of Uganda, Statutory Instrument 278-1, Marketing of Infants and Young Child Foods, Kampala, 2000. http://www.ugandigitalawlibrary.com/lawlib/consolidated_edition.asp?page $=1$ $\underline{3}$ [Accessed 13/8/2007].

22. UHRC (Uganda Human Rights Commission) Towards the Implementation of the Human Right to Adequate Food in Uganda, Kampala, UHRC, 2004.

23. UHRC. $10^{\text {th }}$ Annual Report to the Parliament of the Republic of Uganda, Kampala, Uganda Human Rights Commission, 2007.

24. FAO. Voluntary Guidelines to Support the Progressive Realization of the Human Right to Adequate Food in the context of National Food Security, Rome, FAO, 2005. http://www.fao.org/docrep/meeting/008/J3345e/j3345e01.htm\#a1 [Accessed 15/10/2007]. 


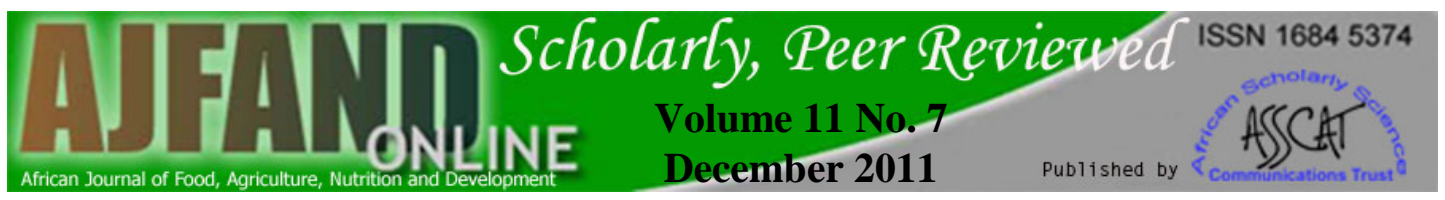

25. AU (African Union) Maputo Declaration on Agriculture and Food Security, Maputo, AU, 2003. http://www.africa-

union.org/Official_documents/Decisions_Declarations/Assembly\%20final/Ass embly\%20\%20DECLARATIONS\%20\%20-\%20Maputo\%20\%20FINAL5\%2008-08-03.pdf [Accessed 18/10/2007].

26. MAAIF (Ministry of Agriculture, Animal Industry, and Fisheries) Development Strategy and Investment Plan 2005/06 - 2007/08, Entebbe, MAAIF, 2006.

27. MFPED (Ministry of Finance, Planning, and Economic Development) Background to the Budget for the Financial Year 2006/07, Kampala, MFPED, 2006.

28. MFPED. Background to the Budget for the Financial Year 2007/08. Kampala, Ministry of Finance, Planning and Economic Development, 2007. http://www.finance.go.ug/docs/BTTB_07.pdf [Accessed 20/10/2007].

29. Omara JA Promoting A Rights-Based Approach to Food and Nutrition Security in Uganda. In: Eide, WB and U Kracht (Eds). Food and Human Rights in Development, Volume II, Antwerpen, Intersentia, 2007; 7: 161-180.

30. Rukooko BA Perceptions of the right to food in Uganda: Results from a study. In: UHRC, Towards the Implementation of the Right to Adequate Food in Uganda. Kampala, UHRC, 2004; 8: 77-103. 